\title{
THE PROHIBITION OF THE MUSLIM HEADSCARF: CONTRASTING INTERNATIONAL APPROACHES IN POLICY AND LAW
}

\author{
Timothy Welch
}

\section{INTRODUCTION}

Law and state policy towards the Muslim headscarf differs widely from country to country. ${ }^{1}$ Western states in which the wearing of the headscarf is, or has been, a contentious issue, tend to follow one of two broad theoretical approaches: assimilationalist or culturally pluralist, although rarely in a pure form. Often policy will be made up of one, whilst containing threads of the other.

This article will focus on the law and state policy predominantly in six countries where the headscarf issue has arisen, and where different political or legal approaches have been adopted, giving rise to different results or consequences. Often the veil debates in each country will give rise to the same broad issues. For example, integration, religious freedom, secularity and health and safety are all debated in respect of the Muslim headscarf. However, it is often the case that one issue will be more important or prevalent in one particular country than in another.

For example in the UK integration has been highlighted in the recent debates, but in the US the concerns rest with the concept of religious freedom, per se. In France and Turkey there has been a need to protect secularism, where the veil has been particularly attacked as a form of pressure by Muslims on others or else regarded as a symbol of the oppression of women. Bans on the headscarf have been attempted in Germany based on employment law and in Canada on health and safety grounds. In other European countries concerns have centred on immigration issues or public security. State policy tends to be driven by various factors including the particular state's historical makeup, immigration and demography, public opinion and political pressure, as well as the theoretical issues which underlie and inform the debate.

\section{ISLAMIC DRESS}

Before embarking on this comparative study on the Muslim headscarf it is necessary to make a few observations about Islamic dress which differs widely in many countries and is found in many different forms. Some women

\footnotetext{
${ }^{1}$ See Leyla Sahin v Turkey Application 44774/98 ECHR Paras 53 - 57.
} 
wear only a head covering, leaving the face visible. This has different names but is more commonly known, and will be referred to here, as the hijab. ${ }^{2}$ The jilbab is an "unfitted, long sleeved, ankle length gown." 3 The niqab is a term for cloth which covers the body and entire face, leaving only the eyes visible. ${ }^{4}$ The burka is an all enveloping robe which covers the entire body except for the eyes which are concealed under a net. In this article the term headscarf will be used generically in referring to any form of Islamic head covering, but the correct terms described above will be recalled when referring to a specific item.

It is a matter of contention as to whether or not the wearing of Islamic dress is a religious requirement, obligatory on Muslims and required by the Koran. This is debated amongst Islamic scholars and Muslims alike. Even where it can be agreed that there is some form of obligatory dress requirement, there is little consensus as to what form this should take. ${ }^{5}$ This article does not seek to answer, or even attempt to answer what is really a theological question. Here, the contention from the beginning and throughout is that the wearing of any Islamic dress is a matter of faith. Faith can take many different forms; it can be personal and subjective. It is not therefore possible to quantify reasons for the wearing of any form of Islamic dress nor is there a desire to attempt this but it is accepted ultimately that it is a manifestation of religious belief in a legal sense. ${ }^{6}$ This is widely accepted. Indeed of all the countries which are discussed below there have been no serious legal arguments advanced which contend that Islamic dress, in any of the forms which it may take, is not an expression of faith in one form or another, and certainly no court has reached such a conclusion.

\section{ASSIMILATION AND CULTURAL PLURALISM}

When examining the law and state policy in western countries, in respect of the wearing of Islamic head coverings, it is useful to have in mind two

${ }^{2}$ Fadaw El Guindi, s v hijab. The Oxford Encyclopaedia of the Modern Islamic World (Oxford University Press 1995.

${ }^{3}$ Ibid.

${ }_{5}^{4}$ Ibid.

${ }^{5}$ Shadid W and Van Koningsveld, Muslim Dress in Europe: Debates on the Headscarf, Journal of Islamic Studies, 2005 16:1 pp35-61.

${ }^{6}$ For example this is the case with the ECHR see Article 9.1 and Leyla Sahin v Turkey Application

44774/98 ECHR, the ICCPR see Article 18 (1) and General Comment Number 22 of the United Nations Human Rights Committee, adopted on 20 July 1993 Doc CCPR/C/21/Rev1/Add.4. 
broad policy approaches which, as Sebastian Poulter points out, ${ }^{7}$ most theoretical analysis, in respect of state response to ethnic diversity, tends to focus; the dichotomy between assimilation, on the one hand, and cultural pluralism, on the other. ${ }^{8}$

Assimilation entails "the absorption of minorities into the mainstream culture of the majority community." Dominant British social attitudes, ${ }^{10}$ as well as recent political opinion, ${ }^{11}$ appear to support this view. However, the United Kingdom, on the whole, has not favoured assimilation as a policy option. At first sight, assimilation might appear to smack of intolerance. However, Poulter points out, there are "rational arguments in favour of assimilation which merit serious consideration." 12

Assimilation can go some way in guarding western values, by preventing departure from minimum standards of acceptable behaviour; it can promote equality before the law in its failure to allow special legal minority status; it can, it is argued, allow minorities to break free from a cycle of disadvantage and discrimination-presumably this is done by making everybody the same. Lastly assimilation can prevent physical segregation within communities. ${ }^{13}$

This approach has largely formed French thinking in respect of religious insignia in schools. Indeed such an approach is highlighted in French public opinion, ${ }^{14}$ history ${ }^{15}$ and law. ${ }^{16}$

Cultural pluralism on the other hand signifies a very different approach. "Advocates of cultural pluralism not only seek to affirm the value of greater diversity in enriching the overall life of the nation, they also reject the notion that minorities should be encouraged or induced to surrender their identities in

\footnotetext{
${ }^{7} \mathrm{~S}$ Poulter, Muslim headscarves in school: contrasting legal approaches in England and France, Oxford J Legal Studies 1997 17: 43-74

${ }^{8} \mathrm{~S}$ Poulter, Muslim headscarves in school: contrasting legal approaches in England and France, Oxford J Legal Studies 1997 17: P 46.

${ }^{9}$ Ibid P 46.

${ }^{10}$ Hence the old saying; when in Rome, do as the Romans do.

11 Harman H, Why I want to see the veil gone from Britain, available at www.newstateman.com/200610160019; Should immigrants try to be 'more British'? BBC, Wednesday, 12 December, 2001.

${ }^{12} \mathrm{~S}$ Poulter, 'Muslim headscarves in school: contrasting legal approaches in England and France', Oxford J Legal Studies 1997 17: P 47.

${ }^{13}$ S Poulter, Muslim headscarves in school: contrasting legal approaches in England and France, Oxford J Legal Studies 199717.

${ }^{14}$ The war of the headscarves, Feb 5th 2004, The Economist.

${ }^{15}$ David Howarth and Georgios Varouxakis, Contemporary France: An Introduction to French Politics and Society, Oxford University Press, London 2003.

${ }^{16}$ For example the principle of Laccite, provided for in 1905.
} 
order to gain economic advancement." 17 Such an approach requires a careful balance; it is generally accepted ${ }^{18}$ that there should be limitations in allowing for diversity, ${ }^{19}$ nevertheless allowances must be made so as to respect diversity and minority identity. ${ }^{20}$

\section{THE UNITED KINGDOM}

In the UK between 1948 and 1956 assimilation had been considered a desirable policy approach; ${ }^{21}$ this is demonstrated in statements made by politicians of the time. However a 1966 speech given by Lord Jenkins, the then Home Secretary, highlighted a shift in British thinking: "I define integration...not as a flattening process of assimilation but as equal opportunity, coupled with cultural diversity, in an atmosphere of mutual tolerance." "This position was reaffirmed by John Major, as Prime Minister, who said "It is a fundamental objective of the UK Government to enable members of ethnic minorities to participate freely and fully in the economic, social and public life of the nation, with all the benefits and responsibilities which that entails, while still being able to maintain their own culture, traditions, language and values." 23

More recently, David Blunkett, on the other hand, appeared to support a shift back towards assimilation when he said this; "If we are going to have social cohesion we have got to develop a sense of identity and a sense of belonging." ${ }^{24}$ One might well question whose sense of identity he is suggesting we develop. Blunkett refers to this as "shared identity based on membership of a political community, rather than forced assimilation." 25 It was around this time that the Home Office introduced "citizenship classes". ${ }^{26}$

${ }^{17}$ S Poulter, Muslim headscarves in school: contrasting legal approaches in England and France, Oxford J Legal Studies 1997 17: P 48.

${ }^{18}$ S M Poulter (1987) 'Ethnic Minority Customs, English Law and Human Rights', ICLQ, vol. 36, pp. 589-615.

${ }_{19}$ Certain minimum standards will not be compromised, for example female circumcision.,

${ }^{20}$ For example Sikhs are exempt from wearing protective helmets on motorcycles.

${ }^{21}$ S Poulter, Muslim headscarves in school: contrasting legal approaches in England and France, Oxford J Legal Studies 199717.

${ }^{22}$ Ibid page 48.

${ }^{23}$ Ibid see page 49.

${ }^{24}$ Independent on Sunday 9 December.

${ }^{25}$ What does citizenship mean today? Sunday September 15, 2002 Observer.

${ }^{26} \mathrm{http}: / /$ www.ind.homeoffice.gov.uk/british_citizenship/english/homepage.html. 
Recently the issue of minority integration has returned to the forefront of political thinking, with the focus placed firmly on the Muslim veil. The spark which ignited this recent and ongoing debate came from comments made by Jack Straw that the veil is a "visible sign of separation". This view was quickly backed by senior cabinet ministers, for example Harriet Harman who said that women are held back by the veil, which is "an obstacle to women's participation, on equal terms, in society". ${ }^{27}$ Tony Blair also entered the debate stating that the veil is a "mark of separation which made some outside the [Muslim] community feel uncomfortable". ${ }^{28}$

Much of the recent headscarf debate in the UK has arisen in respect of and focused upon the niqab and, as will be seen below, practical arguments have been made against the wearing of the niqab in schools and other institutions, such as in courts. However at root the issue appears to be the integration, or perhaps assimilation, of minorities into mainstream British society. To that end much of the debate has spilled over onto the wearing of the headscarf in general. Certainly some generically view Islamic head coverings as a deviation from or direct affront to integration into mainstream British society.

In an article published in The Times Saira Khan, ${ }^{29}$ contestant on BBC's "Apprentice", made a scathing attack on the headscarf which she viewed as "particularly wrong in Britain." 30 She said that it "sends out a clear message; I don't want to be part of your society". ${ }^{31}$ Khan is not alone in this line of thinking, which appears to be shared by the Archbishop of York who said "the veil does not conform to norms of decency". ${ }^{32}$ Laws which prohibit the headscarf also have the support of the Vatican, endorsed in a statement made by Cardinal Martoni who said this: "it [prohibition] seems elementary to me and it is quite right that the authorities demand it". ${ }^{33}$ These statements show a clear push towards a policy of assimilation. The express hostility towards the Muslim headscarf in recent months has been rather worrying. A society in

27 Harman $\mathrm{H}$, Why I want to see the veil gone from Britain, available at www.newstateman.com/200610160019.

${ }^{28}$ Blair's concerns over face veils, BBC News, Tuesday, 17 October 2006: Jones G, Blair wades into Muslim veil row, available at

http://www.telegraph.co.uk/news/main.jhtml?xml=/news/2006/10/17/ublair.xml.

${ }^{29}$ Khan. S, Why Muslim Women Should Thank Straw, The Times October 92006.

${ }^{30}$ Ibid.

${ }^{31}$ Ibid.

${ }^{32}$ Petre J, BBC frightened of criticising Islam, says archbishop, The Telegraph $15^{\text {th }}$ November 2006.

${ }^{33}$ Willey D, Vatican enters Muslim veil debate, BBC14 November 2006. 
which our choice of dress is restricted or regulated at law is of deep concern and, as the Archbishop of Canterbury points out "politically dangerous". ${ }^{34}$

Khan however advances a simple but misconceived solution to the recent dilemma; immigrants who come to Britain should fit into the society which they have chosen as their home. Khan cites as an example concessions made by her own mother when first arriving in the UK: "Without making any fuss she removed her scarf at work and put it back on when she clocked out". ${ }^{35}$ Khan also offers some practical advice to those who find their cultural or religious practice in conflict with mainstream social norms: "If you don't want to integrate, then what the hell are you doing here? Why don't you just go and live in an Islamic country?" 36 However Khan's approach appears to favour an outright ban on Islamic head coverings in the public sphere which is on the extreme and goes some way towards missing the point, which is this: Western, liberal, democracies are, or at least profess to be, free, tolerant societies which offer their citizens and residents freedom of expression, religion and freedom of choice. When approached from this position, Khan's question - "what the hell are you doing here?"-perhaps requires a different answer than that which she provides: people come to Britain because they are afforded rights: the right to freedom of religion and manifestation of religious belief.

However it is accepted that in a culturally pluralistic society there must be, and are, limitations. ${ }^{37}$ There must be respect for religion, but the rights and freedoms of others are important also. In the veil context it could be that what we are seeing in the UK is the thrashing out of the issues, prior to a balance being found. It may be that, if the wearing of the niqab adversely impacts on the rights and freedoms of others, then in certain and limited circumstances restrictions may have to be made. This was the approach taken by a school in West Yorkshire. ${ }^{38}$

Headfield Church of England Junior School in Dewsbury suspended a classroom assistant, who refused to remove her niqab, arguing that children could not hear or understand the assistant and the veil was thus interfering with pupils learning. ${ }^{39}$ This was accepted by the local MP Shalad Melik ${ }^{40}$

${ }^{34}$ Gledhill R, Let people wear cross or veil, says Archbishop, The Times $27^{\text {th }}$ October 2006.

${ }^{35}$ Khan. S, Why Muslim Women Should Thank Straw, The Times October 92006. ${ }^{36}$ Ibid.

${ }^{37}$ Poulter, S.M (1987) 'Ethnic Minority Customs, English Law and Human Rights', ICLQ, vol 36, pp. 589-615.

${ }^{38}$ Headfield Church of England Junior School Dewsbury West Yorkshire.

${ }^{39}$ Norfolk A, Suspended Teacher should have removed Veil, say Muslim Leaders, The Times 14 October 2006.

${ }^{40}$ MP for Dewsbury. 
who said it was reasonable for the school to ask that the veil be removed. ${ }^{41}$ This has also been the approach taken by Imperial College London which banned the niqab from university premises, but has allowed girls to wear the hijab. ${ }^{42}$ This is a compromise which has ministerial support. ${ }^{43}$ Perhaps it is this kind of balance that the country must find.

However when viewed from a religious freedom perspective this is not as reasonable as first it might appear. Religious expression is a subjective concept measurable only by the extent an individual feels they are manifesting their religious belief. In the veil context wearing the hijab in place of the niqab can be beyond compromise because for some at least, the hijab can be no replacement, as it is simply not in accordance with or a manifestation of their personal religious belief. ${ }^{44}$

Nevertheless as Poulter points out, in a multi ethnic society limitations have to be made ${ }^{45}$ and therefore compromises must be found. It is not possible to say what form this will take in the UK as the dust has yet to settle. Perhaps it must be so that where the veil is genuinely and substantially interfering with, and infringing upon, the rights and freedom of others, and where no suitable alternative measures or compromise can be found, restrictions must be made. Indeed provision is made for restrictions of religious practice under Article 9 (2) of the European Convention on Human Rights. However in that regard any limitation in respect of any item must be made in accordance with strict applications of proportionality and high thresholds should be met. ${ }^{46}$ Making bans on the manifestation of religion and religious belief is not something which should be taken likely.

Though there has clearly been a shift in political thinking towards the veil in the U.K, there has been no expressly stated desire to legislate against it, as has been the case in France where a ban has been made against the wearing of all Islamic head coverings and other religious insignia in French state schools. The French ban, which is discussed later, was reasoned by a desire to protect

${ }^{41}$ Norfolk A, Suspended Teacher should have removed Veil, say Muslim Leaders, The Times 14 October 2006.

${ }^{42}$ Tarlo E, The Hidden Features of the Face Veil Controversy, $23^{\text {rd }}$ October 2006, available at www.open.ac.uk/arts/fergson -centre/discussion-docs/disc-etarlo-veil23octo06.htm.

${ }^{43}$ Higher Education Minister Bill Rammell supports this veil, see - Beyond Unreasonable Expectations, The Guardian, $11^{\text {th }}$ September 2006.

${ }^{44} R$ (On the Application of Begum) $v$ Headteacher and Governors of Denbigh High School HL [2006] UKHL 15, [2006] ALL ER (D) 320 (MAR) (Approved Judgement).

${ }^{45}$ S M Poulter, (1987) 'Ethnic Minority Customs, English Law and Human Rights', ICLQ, vol 36, pp 589-615.

${ }^{46}$ A requirement of both Article 9 (2) ECHR and Article 18 (3) ICCPR. 
the French secular state. ${ }^{47}$ This is not an interest the UK can be said to share. Under Charter VI of the School Standards and Frameworks Act 1988 provision is made for worship and religious education in British state schools. The UK is not a secular state, and it would not be possible to defend a ban on the same basis as have the French without a significant overhaul of United Kingdom educational law and schooling standards. However attempts have been made, and continue to be made, to ban the headscarf in British state schools, and other public institutions

\section{The Denbigh High School Case}

In 2002, 15 year old Shabina Begum was sent home from school for refusing to remove her jilbab (long sleeved, ankle length gown). Her case was recently heard by the House of Lords and provides the best indication as to the current law in the UK in respect of the veil in British public institutions.

Ms Begum had claimed that wearing the jilbab was a manifestation of her religious belief, but the school had insisted that only the prescribed variation of the school uniform may be worn. Guidance from the Department of Education and Skills states that "whilst pupils must adhere to a school uniform policy, schools must also be sensitive to the needs of different cultures, races and religions. Schools are expected to accommodate these needs, within a general uniform policy". ${ }^{48}$ However the school argued it had done just that.

Denbigh High School is a school which has pupils from many different religious and ethnic backgrounds. ${ }^{49}$ Prior to issuing a school uniform the school had entered into consultation with religious leaders from all faiths. It subsequently opted for as a uniform the Shalwar Kameez. ${ }^{50}$ This, the school was advised, could be worn by children of different faiths, ${ }^{51}$ and also satisfied

47 RAPPORT AU PRÉSIDENT DE LA RÉPUBLIQUE 2003, available at; http://lesrapports.ladocumentationfrancaise.fr/BRP/034000725/0000.pdf; Statement made by Jacques Chirac, 28/01/04, available at: www.info-franceusa.org/news/statmnts/2004/chirac_secularism012804.asp.

${ }^{48}$ Department for Education \& Skills;

www.teachernet.gov.uk/management/atoz/u/uniform/.

${ }^{49} R$ (On the application of Begum) v Headteacher and Governors of Denbigh High School, Queens Bench Division [2004] ELR 374 Paras 22 - 29.

${ }^{50}$ Traditional "Punjabi suit" consisting of long knee, calf, or even ankle length loose fitting.

${ }^{51}$ Opinion of Legal Department to the Islamic Cultural Centre in Regents Park London, See $R$ (On the application of Begum) $v$ Headteacher and Governors of Denbigh High School, Queens Bench Division [2004] ELR 374. 
the requirements of the Islamic faith. ${ }^{52}$ The school insisted that this should be worn by all pupils, including Begum.

The Court of Appeal however held that Begum's right to manifestation of religious belief under Article 9 of the European Convention on Human Rights ${ }^{53}$ had been infringed. ${ }^{54}$ It was for the school to justify an interference with Begums Article 9 right under the conditions set out in Art 9 (2). ${ }^{55}$ But the school had not approached the issue from this direction; rather it had merely insisted that the uniform of compromise must be worn. The court did however leave some room for manoeuvre stating that "It would not be impossible for the school, if the matter was approached from the right direction, to justify the schools policy with regard to another pupil adopting the same position". ${ }^{56}$ The court even provided some guidance to schools. ${ }^{57}$

The House of Lords ${ }^{58}$ did not agree. ${ }^{59}$ The House held that the Court of Appeal's approach had been procedurally mistaken for three main reasons:

\begin{abstract}
"First, the purpose of the Human Rights Act 1998 was not to enlarge the rights or remedies of those in the United Kingdom whose Convention rights have been violated but to enable those rights and remedies to be asserted and enforced by the domestic courts of this country and not only by
\end{abstract}

${ }^{52}$ Ibid.

53 European Convention on Human Rights, Article 9 (1): Everyone has the right to freedom of thought, conscience and religion; this right includes freedom to change his religion or belief, and freedom, either alone or in community with others and in public or private, to manifest his religion or belief, in worship, teaching, practice and observance.

${ }^{54} R$ (On the application of Begum) v Headteacher and Governors of Denbigh High School, Queens Bench Division [2004] ELR 374.

${ }^{55}$ European Convention on Human Rights Article 9 (2): Freedom to manifest one's religion or beliefs shall be subject only to such limitations as are prescribed by law and are necessary in a democratic society in the interests of public safety, for the protection of public order, health or morals, or the protection of the rights and freedoms of others.

${ }^{56}$ Judgement of Mummery LJ, $R$ (On application of Begum) $v$ Headteacher and Governors of Denbigh High School 140, Court of Appeal (Civil Division) [2005] EWCA CIV 199, [2005] ALL ER, Para 88.

${ }_{58}^{57}$ Ibid, See Lord Brooke Paras 81 -82.

${ }^{58} R$ (On the Application of Begum) $v$ Headteacher and Governors of Denbigh High School HL [2006] UKHL 15, [2006] ALL ER (D) 320 (MAR) (Approved Judgement).

${ }^{59}$ Lord Nicholls of Birkenhead and Baroness Hale of Richmond dissenting. 


\section{THE PROHIBITION OF THE MUSLIM HEADSCARF: CONTRASTING INTERNATIONAL APPROACHES}

recourse to Strasbourg ${ }^{60} \ldots$ Secondly, it is clear that the court's approach to an issue of proportionality under the Convention must go beyond that traditionally adopted to judicial review in a domestic setting ${ }^{61} \ldots$ Thirdly, and as argued by Poole in his article cited above, pages 691-695, I consider that the Court of Appeal's approach would introduce 'a new formalism' and be 'a recipe for judicialisation on an unprecedented scale'... what matters in any case is the practical outcome, not the quality of the decision-making process that led to it." ${ }^{\prime 2}$

The House of Lords viewed the issue of interference as a debatable question, placing particular significance on justification under Article 9 (2). In relying on Leyla Shain v Turkey, ${ }^{63}$ Lord Bingham said this:

"the need in some situations to restrict freedom to manifest religious belief; the value of religious harmony and tolerance between opposing or competing groups and of pluralism and broadmindedness; the need for compromise and balance; the role of the state in deciding what is necessary to protect the rights and freedoms of others; the variation of practice and tradition among member states; and the permissibility in some contexts of restricting the wearing of religious dress." 64

The House concluded that "the school was entitled to consider that the rules about uniform were necessary for the protection of the rights and freedoms of others". ${ }^{65}$ This ruling was however restricted to the Denbigh case and their Lordships made very clear it applied to no other:

"It is important to stress at the outset that this case concerns a particular pupil and a particular school in a particular place at a particular time. It must be resolved on facts, which are now,

${ }^{60} R$ (On the Application of Begum) $v$ Headteacher and Governors of Denbigh High School HL [2006] UKHL 15, [2006] ALL ER (D) 320 (MAR) (Approved Judgement)

- para 29.

${ }^{61}$ Ibid para 30.

${ }^{62}$ Ibid para 31.

${ }^{63}$ Leyla Sahin v Turkey (Application no. 44774/98) 29 June 2004.

${ }^{64} R$ (On the Application of Begum) v Headteacher and Governors of Denbigh High School HL [2006] UKHL 15, [2006] ALL ER (D) 320 (MAR) (Approved Judgement)

- para 29.

${ }^{65}$ Ibid para 58. 
for the purposes of the appeal, agreed. The House is not, and could not be, invited to rule whether Islamic dress, or any other feature of Islamic dress, should be permitted in the schools of this country. That would be a most inappropriate question for the House in its judicial capacity, and it is not one, which I shall seek to address." 66

Since the Denbigh ruling there have been further bans made on the headscarf. One related to a prohibition imposed on a legal representative appearing before an immigration tribunal. She was asked to remove her niqab after a judge said he could not hear her properly. ${ }^{67}$ Following the incident $\mathrm{Mr}$. Justice Hodge offered judges guidance on the wearing of veils in courts and tribunals where he said this: "Legal advisers and solicitors may wear the Islamic veil in court unless it interferes with the interests of justice". ${ }^{68}$ Lord Chief Justice Lord Phillips has said that full rules are being drawn up. ${ }^{69}$ In another, the case of the niqab in the school in West Yorkshire mentioned above, an employment tribunal found that there had been no religious discrimination and upheld the schools decision, but awarded the teaching assistant $£ 1,100$ for injury to feelings. ${ }^{70}$ The assistant has said she will appeal the decision.

More recently still, and ongoing at the time of writing, a school in Buckinghamshire ${ }^{72}$ has prevented a 12 year old girl from wearing her niqab. The girl, or moreover her father, ${ }^{73}$ initiated legal proceedings by way of judicial review. ${ }^{74}$ At the High Court counsel for the girl, known only as X, argued that the schools decision to ban the niqab was irrational, ${ }^{75}$ and

\footnotetext{
${ }^{66}$ Ibid para 2.
}

${ }^{67}$ Lawyers 'can wear veils in court' BBC Friday, 10 November available at http://news.bbc.co.uk/1/hi/uk/6134804.stm.

${ }^{68}$ Ibid.

${ }^{69}$ Ibid.

70 MP tells veil woman 'let it go' BBC 20 October 2006 available at http://news.bbc.co.uk/1/hi/uk_politics/6069012.stm.

${ }^{71}$ Ibid.

${ }^{72}$ At the time of writing the identiy of the and the school, and the 12 year old girl involved had not been released to the public due to an anonymity order. See 'Parent fights over child's veil' Wednesday, 24 January 2007 BBC News; available at http://news.bbc.co.uk/2/hi/uk_news/education/6294225.stm.

75 'Parent fights over child's veil' Wednesday, 24 January 2007 BBC News; available at http://news.bbc.co.uk/2/hi/uk news/education/6294225.stm.

74 'Legal Fight for School Veil' 2 February 2007 BBC News, available at http://news.bbc.co.uk/go/pr/fr/-/2/hi/uk_news/education/6341815.stm .

75 'School veil ban 'irrational', court told' 8 February 2007, The Guardian. 
contrary to Article 9 (1) ECHR ${ }^{76}$ The Judge at the High Court hearing, $\mathrm{Mr}$ Justice Silber, made several comments which raised the issue of protecting the rights of others who may be affected by students wearing the veil. For example he said that "everyone knows these days how security-conscious head teachers have to be at school. They have to be able to glance around and recognise who's there." He further stated that "barristers had to react to judges' facial expressions, in the same way that teachers reacted to pupils' facial expressions". ${ }^{77}$ Such comments may be seen as somewhat revealing, however the judge stressed that he was not expressing an opinion one way or the other. ${ }^{78}$ It will be interesting to see how this case is decided and whether, whatever the decision may be, it is appealed and heard in a higher court such as the House of Lords, or at Strasbourg. Certainly a ruling on the issue of the niqab in schools could add some legal clarity to this specific question of law which increasingly the courts are being asked to rule upon.

As it stands, the law is not altogether clear in the UK. Whilst Article 9 will apply the House of Lords has not given specific guidance as to how this should be applied in veil cases, and one must look to Strasbourg case law which provides states with a wide margin of appreciation in that regard. This is discussed in detail later. The Denbigh case does appear to suggest that the House of Lords will uphold a ban, on what appears to be a low level of interference for the purposes of Article 9 (2).

This position, coupled with the British political hostility towards the veil, is somewhat in contrast with the approach taken in the United States where religious freedom is fiercely protected.

\section{THE UNITED STATES}

In the US religion and religious freedom are highly regarded issues considered extremely important to the nation as a whole. ${ }^{79}$ The Americans have approached religious freedom from a cultural pluralistic position, although there are limitations. For some in the US, America gets religious freedom "remarkably right" 80 but others take the view that the US Supreme Court demonstrates a "clear and unmistakable hostility towards religious

\footnotetext{
${ }^{76}$ Ibid.

${ }^{77}$ Ibid.

${ }^{78}$ Ibid.

${ }^{79}$ Hearing before Subcommittee on the Constitution, Civil Rights and Property Rights of the Senate Judiciary Committee, United States Senate, One Hundred Eighth Congress Beyond the Pledge of Allegiance: Hostility to Religious Expression in the Public Square, June 8, 2004.

${ }^{80}$ Ibid Testimony of Melissa Rogers P 146.
} 
expression" $"$. . . and. . "local Governments take a similar view". ${ }^{82}$ Rarely do Americans express an opinion that religious freedom has gone too far. This approach to religious freedom, which is reflected in US law, ${ }^{83}$ provides a significant level of protection for the wearing of the Islamic veil.

The First Amendment of the United States Constitution ${ }^{84}$ protects the free exercise of religion, ${ }^{85}$ and prohibits the government from passing laws which establish an official religion making preference of one over another. ${ }^{86}$ The US Supreme Court, which is responsible for the legal interpretation of the Constitution, has from an early stage upheld the importance of religious belief under the free exercise clause. Although the court has made clear there are limitations to religious expression and religious freedom is not superior to the law, ${ }^{87}$ Supreme Court jurisprudence offers the headscarf a high level of protection.

\section{Tinker v Des Moines School District}

"It can hardly be argued that either students or teachers shed their constitutional rights to freedom of expression at the school gates." 88 This was the view expressed by Mr. Justice Fortas in the Supreme Court's ruling in Tinker $v$ Des Moines. ${ }^{89}$ A comment which is revealing of the strident defence of religious liberty taken by the Supreme Court in the US.

The court in Tinker held that the wearing of black armbands by students in protest against the war in Vietnam was closely akin to "pure speech" protected under the free exercise clause. Although the court did not consider the issue of the headscarf, or religious dress, the ruling offers a significant degree protection to girls wishing to wear their headscarves in schools, and the court further formulated a test which may be applied in respect of the same: expression under the first amendment, which includes religion and the manifestation of religious belief, may not be interfered with where it does not

\footnotetext{
${ }^{81}$ Ibid Opening Statement of Hon John Cornyn, US Senator State of Texas $\mathrm{p} 3$.

82 Ibid.

${ }^{83}$ Not least the First Amendment of the Constitution.

${ }^{84}$ First Amendment:
}

"Congress shall make no law respecting an establishment of religion, or prohibiting the free exercise thereof; or abridging the freedom of speech, or of the press; or the right of the people peaceably to assemble, and to petition the Government for a redress of grievances."

${ }^{85}$ Free Exercise Clause.

${ }^{86}$ Establishment Clause.

${ }^{87}$ Davis v Beason, 133 US 333 (1890).

${ }^{88}$ Ibid.

${ }^{89}$ Tinker v Des Moines School District, 393 US 503 (1969).

${ }^{90}$ Ibid per Mr Justice Fortas. 
"materially and substantially interfere with the requirements of appropriate discipline in the operation of the school." "91 There are no cases in the US which such a line of argument has succeeded in respect of the headscarf.

\section{The Compelling Interest Test}

Traditionally a widely accepted ${ }^{92}$ hoop through which the government must jump in order to restrict religious expression is the "compelling interest test". Here the government is required to show "a compelling interest... which justifies the substantial infringement of an applicant's right to religious freedom", 93 and even then, it must be achieved by the least restrictive means possible. ${ }^{94}$ Where a law unduly burdens the practice of religion, even though neutral on its face and uniformly applicable to all citizens, it will be unconstitutional. ${ }^{95}$ The Supreme Court has therefore been robust in its protection of religious freedom. However in 1990 there was a sea change in the interpretation of the free exercise clause.

In Smith ${ }^{96}$ the compelling interest test was replaced, now allowing for the government to demonstrate merely that a law did not target a particular religion and was neutral and generally applicable. ${ }^{97}$ Under this interpretation a law banning the headscarf therefore could only be upheld where it demonstrably does not target Islam or the wearing of the veil as a religious practice. The Smith decision was extremely unpopular in the US and was responded to by Congress with the passing of the Religious Freedom Restoration Act (RFRA). ${ }^{98}$

The RFRA restored the compelling interest test, although in fact went further than this ${ }^{99}$ and was subsequently struck down as unconstitutional by the Supreme Court. ${ }^{100}$ However many states enacted their own versions of

${ }^{91}$ Ibid.

${ }^{92}$ Introduced in Sherbert v Verner 374 US 398 (1963) see also Wisconsin v Yoder 406 US 205 (1972).

${ }^{93}$ Sherbert $v$ Verner 374 US 398 (1963).

${ }^{94}$ Thomas $v$ Review BD., IND EMPL. SEC DIV, 450 US 707 (1981).

${ }^{95}$ Wisconsin v Yoder 406 US 205 (1972).

${ }^{96}$ Employment Division v Smith, 494 US 872 (1990).

${ }^{97}$ Ibid.

${ }^{98}$ Passed in 1993.

99 The Supreme Court in City of Boerne $v$ Flores, ARCHBISHOP OF SAN ANTONIO, et al (1997) No 95-2074, held that the RFRA forced states to provide more protection than was required by Employment Division $v$ Smith.

${ }^{100}$ City of Boerne v Flores, ARCHBISHOP OF SAN ANTONIO, et al (1997) No 952074. 
the RFRA at state level. ${ }^{101}$ Though slightly confusing, and will doubtless be the subject of further change, the present state of the law is that the RFRA remains as a source of protection, applicable to federal laws. ${ }^{102}$ Tinker is applicable and laws which are discriminatory or targeted will be unconstitutional. Though since Smith there is increased scope for the government to argue for a prohibition of the veil, there remains a reasonably high threshold which must be met.

As a matter of US policy towards the veil, a memorandum issued by Bill Clinton ${ }^{103}$ is indicative of the US administrative approach to religious freedom: "Nothing in the First Amendment converts our public schools into religious free zones". ${ }^{104}$ Under the heading "Student Garb" Clinton provides that "students may display religious messages on items of clothing", ${ }^{105}$ and he mentioned the headscarf in particular where he said this: "When wearing particular attire such as Yamulks and headscarves, during the school day is part of student's religious practice, under the Religious Freedom Restoration Act schools generally may not prohibit the wearing of such items."106

Further guidelines issued in $1995,{ }^{107}$ and which have been said to carry considerable authority, ${ }^{108}$ set out that religious symbols may be "displayed on items of clothing to the same extent that [students] are permitted to display other comparable messages." 109 The guidelines also expressly prohibit religions from being "singled out for suppression." 110 Schools are however afforded "substantial discretion in adapting policies relating to school dress." 111 There is no general right to be "exempted from religiously neutral

${ }^{101}$ Including Arizona, Connecticut, Florida, Idaho, Illinois, Missouri, New Mexico, Oklahoma, Pennsylvania, Rhode Island, South Carolina and Texas. See Douglas Laycock, Theology Scholarships, the Pledge of Allegiance, and Religious Liberty: Avoiding the Extremes but Missing the Liberty, 118 Harv L. Rev 155 (2004).

${ }^{102}$ Gonzales v O Centro Espirita Beneficente União do Vegetal, 546 US (2006).

${ }^{103}$ Then President.

104 Bill Clinton: memorandum dated July 12, 1995 to Attorney General Janet Reno and Secretary of Education Richard W Riley about religious expression in public schools, para 4.

${ }^{105}$ Ibid para 18.

${ }^{106}$ Ibid.

${ }^{107}$ Guidelines on Religious Expression in Schools available at

www.ed.gov/speeches/08-1995/religion.html.

${ }^{108}$ Hearing before Subcommittee on the Constitution, Civil Rights and Property Rights of the Senate Judiciary Committee, United States Senate, One Hundred Eighth Congress Beyond the Pledge of Allegiance: Hostility to Religious Expression in the Public Square, June 8, 2004.

${ }^{109}$ Ibid.

${ }^{110}$ Ibid.

${ }^{111}$ Ibid. 
and generally applicable school dress rules based on religious belief." 112 To that end the guidelines restate the law in Smith. The Bush Administration has also issued guidelines on religious freedom in schools, ${ }^{113}$ and has been praised for its "sensitivity to this issue." 114

An example of the Bush policy towards religious freedom in schools, and here the Muslim headscarf in particular, is highlighted from the case of Nashala Hern, a 12 year old student from Oklahoma who was excluded from her school ${ }^{115}$ for wearing her hijab. This case, reported widely both in the $\mathrm{US}^{116}$ and internationally, ${ }^{117}$ did not invoke a ruling on the headscarf because it was settled out of court. Although the schools lawyers relied on the government guidelines in arguing that "there is no federal right to wear religious attire" 118 it was the government which came to Herne's defence. The Assistant Attorney General for Civil Rights said this: "The Department of Justice will not tolerate discrimination against Muslims or any other religious group." 119 It is not entirely clear why the school took exception to the wearing of the hijab ${ }^{120}$ although it has been suggested this was "particularized hostility towards the Muslim faith." ${ }^{121}$ What is clear is that the school backed down and the issue was resolved in the form of a consent order ${ }^{122}$ in which

${ }^{112}$ Ibid.

113 'Guidance on Constitutionally Protected Prayer in Public Elementary and Secondary Schools' 7 February 2003 US Department of Education, available at www.ed.gov.

${ }^{114}$ Hearing before Subcommittee on the Constitution, Civil Rights and Property Rights of the Senate Judiciary Committee, United States Senate, One Hundred Eighth Congress Beyond the Pledge of Allegiance: Hostility to Religious Expression in the Public Square, June 8, 2004, Testimony of Melissa Rogers p 146.

${ }^{115}$ Muskogee Public School Oklahoma.

116 'Girl's head scarf fuels debate on religious freedom' April 2, $2004 \mathrm{CNN}$ available at http://www.cnn.com/2004/LAW/04/01/hearn/index.html.

117 'US opposes Oklahoma headscarf ban' Wednesday, 31 March, 2004 BBC available at http://news.bbc.co.uk/2/hi/americas/3585377.stm.

${ }^{118}$ Ibid.

${ }^{119}$ Department of Justice Briefing Statement available at www.osdoj.gov/opa/pr/2004/may/04_crt_343.htm.

${ }^{120}$ Other students were allowed to cover their heads on medical grounds, see American Jewish Congress Praises Oklahoma Religious Accommodation Settlement, (May 19 2004) available at http://ajcongress.org/pages/RELS2004/MAY/may04_03htm.

${ }^{121}$ Hearing before Subcommittee on the Constitution, Civil Rights and Property Rights of the Senate Judiciary Committee, United States Senate, One Hundred Eighth Congress Beyond the Pledge of Allegiance: Hostility to Religious Expression in the Public Square, June 8, 2004, Testimony of Melissa Rogers p 146.

${ }^{122}$ Eyvine Hearn (United States Intervenor) v Muskogee Public School. Consent Order CA No: CIV 03-598-S. 
the school made a number of fresh policy decisions on the veil, including a procedure for permitting girls to wear it, and training for teachers in respect of the same. ${ }^{123}$ Perhaps, as one commentator puts it, the school merely "saw the inequity in its practice." 124 On the other hand it may be that the intervention by the government was decisive in the dispute, proving to be an effective protective measure which can be relied upon additionally to rights provided at law.

In spite of this there are however various other examples of restrictions being placed on religious freedom in the US, including on the headscarf. ${ }^{125}$ This may be an accelerating tendency in the US; born perhaps out of an ignorance of Islam, ${ }^{126}$ the law, or from post 911 Islamophobia. In that regard the protection offered at law to those who wear the veil, and robust approach taken by the government, is all the more pressing and a commendable example which other countries may wish to follow.

\section{CANADA}

Canada, like the US but starkly contrasted with some European countries such as France, is a country in which the freedom of religion, and manifestation of religion in the public sphere is protected at constitutional level. ${ }^{127}$ Public opinion in Canada appears to support the wearing of the

${ }^{123}$ Ibid.

${ }^{124}$ Congress Praises Oklahoma Religious Accommodation Settlement, (May 19 2004) available at http://ajcongress.org/pages/RELS2004/MAY/may04_03htm.

125 'Women Sues After Being Ordered to Remove her Headscarf During Prison Visit (Wisconsin), The Associated Press, May 25 2005; Muslim Women Fights to Wear Veil in Driver Licence Photograph, CAIR Press, December 12 2004; Educators Struggle to Uphold Dress Code in Light of Religious Accommodation (Texas) Houston Chronicle, September 192006.

${ }^{126}$ Hearing before Subcommittee on the Constitution, Civil Rights and Property Rights of the Senate Judiciary Committee, United States Senate, One Hundred Eighth Congress Beyond the Pledge of Allegiance: Hostility to Religious Expression in the Public Square, June 8, 2004, Testimony of Melissa Rogers p 146.

${ }^{127}$ Canadian Charter; Fundamental Freedoms:

2. Everyone has the following freedoms:

(a) Freedom of conscience and religion.

(b) Freedom of thought, belief, opinion and expression, including freedom of the press and other media of communication.

(c) Freedom of peaceful assembly.

(d) Freedom of association. 
headscarf, ${ }^{128}$ and the Canadian government has been praised in its approach towards religious freedom. ${ }^{129}$ However, the veil issue has been controversial.

Canadian law offers protection in respect of freedom of religion or sincerely held beliefs, but there are practical limitations placed on this. ${ }^{130}$ It has been held by the Canadian Supreme Court in respect of employment law that a rule "may be discriminatory if it affects one group differently from others to whom it applies."131 This principle, which extends to schools and school children, ${ }^{132}$ will, prima facie, apply to a ban on the headscarf.

The law seeks to strike a balance in Canada ${ }^{133}$ between two sets of conflicting rights; the right to freedom of religion must be "reasonably accommodated" 134 but only to a point of "undue hardship" with regard to regards the accommodating party. ${ }^{135}$ What involves undue hardship amounts to a non-exhaustive list of factors, ${ }^{136}$ including what appears to be an often cited point in Canada; grounds of health and safety. It seems difficult to envisage a position where wearing a headscarf can amount to "undue hardship" given that it ultimately involves merely toleration, rather than, as Perrie Bosset points out "providing material facilities for use in worship"137 as other religious practice might. Nevertheless there have been prohibitions made on wearing the headscarf in Canada. ${ }^{138}$

Irene Waseem, a pupil at a private school in Quebec, ${ }^{139}$ was suspended from her school in 2004 because she refused to remove her hijab. The

${ }^{128}$ See Centre for Research and Information on Canada Document: 'Canadians Reject Ban on Religious Symbols or Clothes in Schools, Majority sees Racial or Religious Background of Party Leaders as Irrelevant' available at www.cric.ca.

${ }^{129}$ US Department of State International Religious Freedom Report 2005: Canada. Available at www.state.gov/g/drl/rls/irf/2005/51630.htm.

${ }^{130}$ For example where there is a bona fide occupational requirement., see Canadian National Railway Co v Canada (Human Rights Comm) and Bhinder (1985), 7 CHRR $\mathrm{D} / 3093$ (SCC).

${ }^{131}$ Ontario Human Rights Commission and O'Malley v Simpsons-Sears (1985) 2 SCR 536551.

${ }_{132}$ CDPQ v CS St Jean-Sur Richelieu (1991) RJQ 30033038.

${ }^{133}$ Ontario Human Rights Commission and O'Malley v Simpsons-Sears (1985) 2 SCR 536551 .

${ }^{134}$ Ibid.

${ }^{135}$ Ibid.

${ }^{136}$ Bosset. P, 'Reflections on the Scope and Limits of the Duty of Reasonable Accomodation in the Field of Religion' Document 2.120-4.20.2 Commission Des Droits De La Personne, 2005.

${ }^{137}$ Ibid.

${ }^{138}$ For discussion see; www.themodernreligion.com/women/hijab_canada2.htm.

${ }^{139}$ Human Rights Complaint in Hijab Case Dropped, CBC News 17 November 2004, available at www.cbc.ca/canada/story/2004/11/16/hijab041116.htm. 
suspension was made despite specific comments made by the Quebec Human Rights Commission in respect of the veil in $1995 .{ }^{140}$ The Commission did not however immediately come to Waseem's defence and was criticised for not having done so. ${ }^{141}$ Certainly other human rights groups were quicker to act. ${ }^{142}$ The Commission eventually made a statement on Waseem's case 2 years later stating that schools must show "necessary and objectively" that a restriction is required. ${ }^{143}$ Although schools may apply this as they see fit. Waseem's case was later resolved out of court.

One possible argument open to an institution in Canada wishing to show that a ban is "necessarily and objectively" required would be to rely on health and safety grounds, which as stated above is increasingly relied on in attempting to justify a ban on religious attire. The issue has been raised in respect of physical education classes where there are concerns that long robes could get caught in equipment. ${ }^{145}$ Also cited as reasons for a ban are, similar to the issues raised in the UK, criticisms of the niqab which conflicts with the health and safety others as it inhibits learning and further can be used as a disguise to cheat in exams. ${ }^{146}$ One wonders how many people cheat on their exams in this way, and whether the problem can possibly be so widespread so as to justify a ban. Health and safety concerns surrounding the hijab must have featured on the mind of Ikea which employs Muslim girls who wear the hijab. However Ikea, rather than making a prohibition, tailored their own brand of hijab which comes with clips to avoid health and safety hazards. ${ }^{147}$ It does not seem unreasonable to ask why schools cannot also take a similar approach.

Health and safety and religious freedom were issues raised in the Canadian case Multani. ${ }^{148}$ Here the Supreme Court found that the banning of a Kirpan ${ }^{149}$ was not proportionate to the objective of maintaining health and safety in a school because the degree of safety sought was excessive and there was little evidence of the Kirpan being used in violent incidents inside of

140 'Quebec private schools must allow hijabs, skullcaps: Human Rights Commission' 16 June 2005 available at www.cbc.ca.

${ }^{141}$ www.muslimcouncil.org/en/2004/11/the-qubec-human-rights-commis.htm.

142 Shariff S, Balancing Competing Rights: A Stakeholder Model for Democratic Schools, Canadian Journal of Education 29, 2 (2006) 476-496.

${ }^{143}$ Ibid.

${ }^{144}$ Human Rights Complaint in Hijab Case Dropped, CBC News 17 November 2004, available at www.cbc.ca/canada/story/2004/11/16/hijab041116.htm.

${ }^{145}$ Shariff S, Balancing Competing Rights: A Stakeholder Model for Democratic Schools, Canadian Journal of Education 29, 2 (2006) 476-496.

${ }^{146}$ Ibid.

${ }^{147}$ www.hijabshop.com.

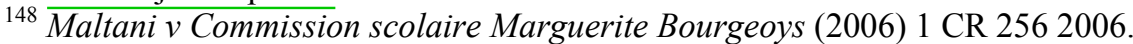

${ }^{149}$ Ceremonial knife worn by people of the Sikh religion. 
schools. ${ }^{150}$ It would seem therefore that whilst health and safety grounds are often cited as reasons for restricting religious freedom, there is a high threshold which must be met as regards the test of proportionality.

\section{FRANCE}

France, like the US has a strict separation of church and state, but in terms of law and policy towards the Muslim veil their positions could scarcely be more different. Where in the US there is a general pluralistic approach towards the headscarf, assimilation and secularity are considered extremely important in France. ${ }^{151}$ French national identity is thought to prevail over individual religious and cultural diversity, a concept in France which has widespread public support. ${ }^{152}$ It is perhaps for historic reasons that this is so.

France, which has a bloody history of religious violence, was "created by conflict, by war and the suppression of alternative identities." "153 The French Revolution of 1789 was a sequence of events which created large divisions between the Catholic Church and state. ${ }^{154}$ In 1905 a law officially provided for the separation of church and state. ${ }^{155}$ The French principle of Laicite is firmly placed in French history, law and national psyche. Poulter provides an interesting example of what this means in practice: "It can be interpreted as a more active secularism, in terms of which the nation is promoted as a fundamentally political society fiercely independent of any religious authority but one which the values of the state can be utilised through the concept of "l'ordre public" to justify interference where necessary with some religious organisations." 156 To that end, religion, religious insignia and the Muslim veil are considered to have no place in French state schools.

The Creil Controversy

${ }^{150}$ Ibid.

${ }^{151}$ S Poulter, Muslim headscarves in school: contrasting legal approaches in England and France, Oxford J Legal Studies 199717.

152 Statement made by Jacques Chirac, 28/01/04, available at: www.info-franceusa.org/news/statmnts/2004/chirac_secularism012804.asp.

153 Judge $\mathrm{H}$ 'The Muslim Headscarf and French Schools', American Journal of Education 111, November 2004, p 2.

${ }^{154}$ Napoleon, who became a virtual dictator of France in 1799, made a deal with the Papacy (Concordat - 1801), which restored certain rights of the Catholic church in France, but it was a compromise. See - Schama, Simon. Citizens: A Chronicle of the French Revolution. New York: Knopf: 1989.

1551905 Law: "The republic assures the right of conscience and guaranties the freedom of cult"

${ }^{156} \mathrm{~S}$ Poulter, Muslim headscarves in school: contrasting legal approaches in England and France, Oxford J Legal Studies 199717 Page 50. 
The headscarf first caused controversy in France in the late 1980s when Muslim girls at a school in Creil were suspended after refusing to remove their hijabs. The matter was referred to the Conseil d'Etat ${ }^{157}$ which held that school children would not be allowed to wear religious insignia which:

"By ostentatious or campaigning nature, consisted as act of pressure, provocation, proselytism or propaganda, or which were aimed at the dignity or freedom of other pupils or members of the school community, or compromised their health or safety or disturbed good order and the peaceful running of the school." 158

This approach was later reaffirmed, ${ }^{159}$ and followed by a ministerial circular. ${ }^{160}$ The debate has thus been raging in France for sometime, but the decision to create a legislative ban on religious insignia is however recent.

\section{The 2004 Legislative Ban}

In 2004, the French Parliament passed a law banning religious insignia in French state schools. ${ }^{161}$ The law followed an investigative committee report, the Stasi Report, ${ }^{162}$ ordered by Jacques Chirac in 2003. ${ }^{163}$ The Stasi Report provides an interesting insight into the French interest $n$ making such a ban.

The Report set out that the overriding interest in creating a ban was a desire to protect the principle of Laicite. The Report was robust and uncompromising to that end: "ostentatious displays of religion violate the secular rules of the French school system."164 Jacques Chirac makes this aim clear: "What is at stake is supporting the principle of secularism, which is one

\footnotetext{
${ }^{157}$ French Council of State.
}

${ }^{158}$ S Poulter, Muslim headscarves in school: contrasting legal approaches in England and France, Oxford J Legal Studies 199717.

${ }^{159}$ Kherouaa [1993] Public Law 198.

160 The circular stated that whilst "discreet insignia was permitted.....ostentatious insignia, which constitute in themselves elements of proselytism or differentiation, are prohibited" For discussion see; S Poulter, Muslim headscarves in school: contrasting legal approaches in England and France, Oxford J Legal Studies 199717.

${ }^{161}$ Law 2004-228 of March 15, 2004.

${ }^{162}$ La Commission Stasi.

${ }^{163}$ President of France - Statement made by Jacques Chirac, 28/01/04, available at: www.info-france-usa.org/news/statmnts/2004/chirac_secularism012804.asp.

164 Rapport au president de la Republique 2003, available at ; http://lesrapports.ladocumentationfrancaise.fr/BRP/034000725/0000.pdf. 
of the pillars of our Republic."165 The law itself applies to all public schools with the exception of universities. It does not apply to state funded private schools, most of which are Catholic. ${ }^{166}$ Whilst the law bans all "conspicuous" religious insignia, ${ }^{167}$ much of the French debate has focused on the Islamic veil.

The Stasi Report made various points on the veil, many of which are not peculiar to France. For example it was argued that the veil constitutes a form of pressure on others who do not wish to wear it, and can act contrary to the interests of gender equality. A view strongly argued by French Feminist groups. ${ }^{168}$ The Muslim headscarf is often attacked as a form of oppression, or as symbolic of fundamentalism, ${ }^{169}$ but this is contextual and the headscarf is not always seen subservient. For example an Italian women with a scarf in Rome is chic, but a Muslim women with a scarf is oppressed and a danger to civilisation. $^{170}$

In placing particular emphasis on the "headscarf as a form of pressure" view the Report stated that women wear it "because their parents, their older brothers, as well as religious groups, oblige them to do so." ${ }^{171}$ However this is simply not always the case, nor is there evidence to suggest it is so in the majority of cases. Women wear the veil for many different reasons; as a way of feeling less emancipated, or as freedom from pressure rather than having succumbed to it. This though is not always accepted. Some argue that women do not wear the headscarf as a matter of choice, even if they think they do; they have in fact merely been sold the idea under a guise. The real position, it is argued, is that the headscarf "stands for mock emancipation and oppression of women in society". ${ }^{172}$ This view sees the veil as a deep and culturally rooted form of pressure on women based on, or developed from, historical male dominance and oppression of women. The problem here is this view holds women to have no choice, to that end its implementation would prevent

165 Statement made by Jacques Chirac, 28/01/04, available at: www.info-franceusa.org/news/statmnts/2004/chirac_secularism012804.asp.

to6 Judge $\mathrm{H}$ 'The Muslim Headscarf and French Schools', American Journal of Education 111, November 2004, p 14.

167 Law 2004-228 of March 15, 2004: 'Religious insignia which exhibits conspicuously a religious affiliation'.

${ }^{168}$ Ni Putes Ni Soumises.

169 Shadid W and Van Koningsveld, Muslim Dress in Europe: Debates on the Headscarf, Journal of Islamic Studies, 2005 16:1 pp 35-61.

${ }^{170}$ Example taken from S Poulter, Muslim headscarves in school: contrasting legal approaches in England and France, Oxford J Legal Studies 199717 p 62.

${ }^{171}$ Union des Organisations Islamiques de France, Lettre ouverte a Monsieur Bernard Stasi, president de la Commission sur la laicite, Paris 5 November 2003.

172 A Feiter, 'Een feministe met een hoofddoek, kan dat? Vier allochtone vrouwen in discussie’, Opzij, May 2001, 22-7. 
them from having any choice; the decision would already been made for on their behalf.

Some women say that they wear the veil as a way of avoiding unwanted male sexual advances, or even attacks. However, even assuming the veil serves this purpose, this may be seen as a form of oppression in itself. An Australian Cleric recently made headlines when he implied women deserved sexual advances or assaults where they do not dress modestly. ${ }^{173}$ To subscribe to this school of thought bears two propositions; firstly women are in some way responsible for male aggression or violence, and secondly men are incapable of sexual self restraint. Both of which are unacceptable and as Ayana Hirshi Ali puts it "insulting". ${ }^{174}$

It is likely that in certain individual situation there is pressure to wear the veil and this may take different forms. But it is not as absolute or common place as the Report suggests. ${ }^{175}$ Banning the veil on this basis, aside from restricting women's free choice, is akin to using a sledgehammer to crack a nut.

With regard to the Reports suggestion that the veil asserts pressure on school girls who do not wish to wear it, this argument is less convincing when looked at statistically. Raja Elhabiti ${ }^{176}$ points out that less than $1 \%$ of French school students wear the veil, and asks "how this small number can exert any kind of pressure on girls who do not wish to wear the headscarf." ${ }^{177}$ There would seem to be a need to strike a balance; those who do not wish, but are pressurised to wear the veil must be protected, whilst consideration should be given to human rights and religious freedom. The French have clearly failed to strike this balance.

As with the UK, immigration and integration have featured highly in the French debate. France has seen large immigration, mainly from North African countries. ${ }^{178}$ Something many in France feel uncomfortable with. ${ }^{179}$

${ }^{173}$ Tran M, 'Australian Muslim leader compares uncovered women to exposed meat' Guardian Unlimited 26 October 2006.

${ }^{174}$ Hirsi Ali A, 'Muslim Women are the Key to Change' The Sunday Times 29 October 2006.

175 Rapport au president de la Republique 2003 ,available at ; http://lesrapports.ladocumentationfrancaise.fr/BRP/034000725/0000.pdf.

${ }^{176}$ Raja Elhabiti Director of Research at Karama: Muslim Women Lawyers for Human Rights.

177 The Veil Controvercy: International Perspectives on Religion in Public Life, The Brookings Center on the United States and Europe and the Pew Forum on Religion and Public Life, 19 April 2004.

178 Joyce Mushaben More than just a Bad-Hair Day: The Head-Scarf Debate as a challenge to Euro-National Identities, available at; www.europanet.org/ conference2004/ papers/I7_Mushaben.pdf. 


\section{THE PROHIBITION OF THE MUSLIM HEADSCARF: CONTRASTING INTERNATIONAL APPROACHES}

France has an estimated population of 5 million Muslims and "Islam is now in numerical terms the second religion." ${ }^{180}$ Le Pen places Muslim immigration at the forefront of his political campaigns, ${ }^{181}$ and has gained worryingly widespread support. France has a "heavy concentration of Muslims in socially disadvantaged areas," has received tough and at times hostile political response. ${ }^{184}$

Some have argued that immigration had created a political interest for banning the veil: the need to allay public opinion, thus preventing moderates from turning to the political right. ${ }^{185}$ The 2004 law was in fact, it is argued, aimed at Islam. ${ }^{186}$ There is little evidence to support this, but were the law aimed at Muslims it would almost certainly breach standards of international law ${ }^{187}$ as well as European Convention law. ${ }^{188}$ However the law is framed in such a way likely to avoid this issue. ${ }^{189}$ In any case, even where it can be argued that the French law was genuinely motivated as a defence of secularity and is non-discriminatory, it must nevertheless meet the standards set out in Article 9 (2) ECHR, which arguably it may not.

${ }^{179}$ Walker D 'Ballot experiments have mixed effect' The Guardian 3 May 2002 available at http://society.guardian.co.uk/localgovelections/story/0,709237,00.html.

${ }^{180}$ Judge $\mathrm{H}$ 'The Muslim Headscarf and French Schools', American Journal of Education 111, November 2004.

${ }^{181} \mathrm{http} / / /$ news.bbc.co.uk/1/hi/world/europe/1943193.stm.

182 Judge H 'The Muslim Headscarf and French Schools', American Journal of Education 111, November 2004.

183 'Paris riot: PM cancels Canada trip' CNN 2 November 2005 available at http://edition.cnn.com/2005/WORLD/europe/11/02/france.riots/.

${ }^{184}$ Nicholas Sarkosy refered to rioters as 'scum' see;

http://edition.cnn.com/2005/WORLD/europe/11/02/france.riots/.

185 'Report outrages France's Muslims' Al Jazeera 13 December 2003, available at http://english.aljazeera.net/NR/exeres/E7BC0591-15BB-4340-937E-

7F3ADDDD487F.htm.

${ }^{186}$ Ibid.

${ }^{187}$ International Covenant on Civil and Political Rights (ICCPR) Article 2 of the obliges all state parties to "respect the rights set forth in these documents without distinction of any kind, such as race, colour, sex, language, religion, political or other opinion, national or social origin, property or other status."

${ }^{188}$ For example Article 14 Prohibition of Discrimination.

The enjoyment of the rights and freedoms set forth in this Convention shall be secured without discrimination on any ground such as sex, race, colour, language, religion, political or other opinion, national or social origin, association with a national minority, property, birth or other status.

${ }^{189}$ For example the French law is framed so as to prohibit all insignia which ' exhibits conspicuously a religious affiliation.' 


\section{GERMANY}

The German constitution would appear to protect religious liberty in Germany: "Freedom of belief, of conscience and the freedom of faith and world outlook are inviolable". ${ }^{190}$ This also extends to the public office: "All German citizens have access to every public office according to their own aptitudes, qualifications and professional abilities. The exercise of civil and civic rights, the admission to public office, as well as the rights acquired in the public service, apply irrespective of religious confession. No disadvantage may arise from affiliation or non-affiliation to a particular confession or world view". ${ }^{191}$ This is not however as higher level of protection as the text might lead one to conclude.

Like France there has been controversy surrounding the wearing of the headscarf in Germany. However, unlike France, the Germans appear to be less concerned with the display of religious insignia by children; rather the issue has arisen in respect of teachers and employment. A 2003 case $^{192}$ involved a German teacher who was prohibited from wearing the hijab ${ }^{193}$ (is definition needed so late on when frequently used before without footnote?) whilst at work. The school ${ }^{194}$ was concerned that the headscarf symbolised a desire for cultural disintegration that was irreconcilable with the states obligation to neutrality. ${ }^{195}$ There were also concerns that the headscarf could have a proselytising effect on children who were at an impressionable age. ${ }^{196}$ To that end similar concerns had been raised in respect of crucifixes. ${ }^{197}$ The Federal Constitutional Court approached the issue from a religious freedom standpoint, holding that the teacher could not be barred from public school employment, since there was no state law banning religious insignia per se. ${ }^{198}$

${ }^{190}$ German Constitution Article 4.

${ }^{191}$ Article 33 German Constitution.

192 The case of Fereshta Ludin - Federal Labour Court 2 AZR 427/01, available at www.bundesarbeitsgericht.de.

${ }^{193}$ Islamic scarf (head covering) see

http://womenshistory.about.com/od/islamicdress./

${ }_{195}^{194}$ Stuttgart School.

195 Fereshta Ludin - Federal Labour Court 2 AZR 427/01, available at www.bundesarbeitsgericht.de.

${ }^{196}$ For a full discussion of this case see; Joyce Mushaben More than just a Bad-Hair Day: The Head-Scarf Debate as a challenge to Euro-National Identities, available at; www.europanet.org/ conference2004/ papers/I7_Mushaben.pdf.

${ }^{197}$ Leicht J. Germany: the Supreme Court Headscarf ruling and the myth of religious neutrality. 9 October 2003. www.wsws.org.

198 Joyce Mushaben More than just a Bad-Hair Day: The Head-Scarf Debate as a challenge to Euro-National Identities, available at; www.europanet.org/ conference2004/papers/I7_Mushaben.pdf. 


\section{THE PROHIBITION OF THE MUSLIM HEADSCARF: CONTRASTING INTERNATIONAL APPROACHES}

The ban was found to have no basis in law. The court therefore found in favour of the teacher, but left room for manoeuvre: there could be grounds in which dismissal on grounds of headscarves or denial of employment might be justified. ${ }^{199}$ German States would not be prevented from making future bans, if they supplied a legal basis for doing so. ${ }^{200}$ Several German State Governments have moved to introduce laws which will enable a ban to be made. These include Bavaria, Hesse, Lower Saxony and Berlin. ${ }^{201}$ The German position is however, considerably different from France; the existing German cases have related exclusively to employment, whilst the French have favoured an outright ban on religious insignia in schools, at a state level. ${ }^{202}$

\section{TURKEY}

Turkey has for many years banned the headscarf in universities, although this rule has not always been strictly applied. Like France, Turkey has argued that a ban is necessary to protect the secular nature of its state. However in contrast to other European states, Turkey has a predominantly Muslim population and an Islamic history. ${ }^{203}$ Nevertheless, also found in Turkey's history is a staunch commitment to a secular society which is fiercely defended by Turkey's ruling elite. ${ }^{204}$

In Turkey, laws relating to a ban on religious clothing in public institutions date back to the foundation of the republic, and the issue has arisen many times since. Turkey's conflict with the headscarf was perhaps at its height in the late 1980s and early 1990s. In 1988 a law $^{205}$ allowing that the veil be worn in universities was struck down by the Constitutional Court as being an affront to the principle of secularism. In 1991 the court made a similar ruling ${ }^{206}$ and in 1997 the military demanded that the prohibition of the

${ }^{199}$ Dagmar Schiek \& Carl von Ossietzky, European Developments - Just a Piece of Cloth? German Courts and Employees with Headscarves, Industrial Law Journal 2004.

${ }^{200}$ Frhr Von A German Headscarf Debate. Brigham Young University Law Review. 2004.

${ }^{201}$ Leicht J Germany: the Supreme Court Headscarf ruling and the myth of religious neutrality. 9 October 2003. www.wsws.org.

202 At the time of writing two German states have proposed a ban: BadenWuerttemberg and Bavaria.

${ }^{203}$ Ottoman Empire.

${ }^{204}$ Mustafa Kemal Ataturk delivered secularity to Turkey.

${ }^{205}$ Law on Higher Education passed by the Motherland Government.

${ }^{206}$ Constitutional Court Judgement no 1991/8, July 1991. 
veil be strictly adhered to, without exception. ${ }^{207}$ Since that time "the headscarf ban has been widely enforced both inside and outside universities." 208

Women in the Turkish Parliament are actively discouraged from wearing the veil. Those who do are met with immense hostility. ${ }^{209}$ Indeed one female MP lost her citizenship after refusing to remove her hijab. ${ }^{210}$ Although in a recent survey 64 per cent of Turks said they would support female MP's right to wear the headscarf, so there is fierce resistance put up in support of secularity when it is perceived as being under threat. ${ }^{211}$

Further, critics of the headscarf ban have been met in Turkey with considerable distain and violence: Human Rights lawyers have been ill treated by the police, and academics that refuse to enforce a ban, have been dismissed. ${ }^{212}$ To that end Turkey, like France, is extremely defensive of secularity, but in contrast Turkey faces far more powerful opposition to it.

In Turkey Islamic religious groups oppose the secular state, preferring an Islamic one in its place. Serious attempts have been made at destabilising the Turkish state so that a fundamentalist agenda can prevail. ${ }^{213}$ "Much of the resistance to the headscarf is inspired by a fear of what might happen if the tables were turned and an outright Islamic regime was making the rules."214 Advocates of the headscarf ban have been targeted. One MP was killed in a

${ }^{207}$ Memorandum to the Turkish Government on Human Rights Watches Concerns with Regard to Academic Freedom in Higher Education, and Access to Higher Education for Women who Wear the Headscarf. Human Rights Watch Briefing Paper 29 June 2004, available at www.hrw.org.

${ }^{208}$ Ibid.

${ }^{209}$ Rainsford S 'Headscarf issue challenges Turkey' BBC 8 November 2006.

210 Kavakci M 'Headscarf Hearsay' May/June 2004 available at www.foreign policy.com.

${ }^{211}$ Rainsford S 'Headscarf issue challenges Turkey' BBC 8 November 2006.

${ }^{212}$ Memorandum to the Turkish Government on Human Rights Watches Concerns with Regard to Academic Freedom in Higher Education, and Access to Higher Education for Women who Wear the Headscarf. Human Rights Watch Briefing Paper 29 June 2004, available at www.hrw.org.

${ }^{213}$ Refah Partisi and Others $v$ Turkey, nos 41340/98, 41342/98, 41343/98 and 41344/98, ECHR 2003.

${ }^{214}$ Memorandum to the Turkish Government on Human Rights Watches Concerns with Regard to Academic Freedom in Higher Education, and Access to Higher Education for Women who Wear the Headscarf. Human Rights Watch Briefing Paper 29 June 2004, available at www.hrw.org. 
targeted explosion, ${ }^{215}$ a judge shot, ${ }^{216}$ and a columnist was killed by a car bomb. ${ }^{217}$

The Turkish Government relied on this position when arguing at Strasbourg that a ban on the headscarf should be upheld, and it was. ${ }^{218}$ This case is discussed below. France has not had its law banning the headscarf challenged at Strasbourg, but it could not argue that its state is under threat in the same way as Turkey had argued. Whilst there are undoubtedly elements of religious fundamentalism of all kinds in France, for example there have been Catholic movements against the state in years past, it cannot be taken as serious proposition that the French State and system of government is at risk of being overthrown.

Critics of the Turkish headscarf ban have however argued that, even if the state is under threat from fundamentalist Islam, the ban on the veil is overly restrictive and disproportionate to that threat. ${ }^{219}$ Further if the state is under threat, it is from fundamentalism not a piece of cloth. Whatever the arguments which can be advanced that the headscarf is symbolic of fundamentalism, it is not always so, and religious fanatics will not disappear because the headscarf is prohibited. The greater impact will be on liberty.

\section{OTHER EUROPEAN COUNTRIES}

The veil row in Holland dates back to at least 1985 when a local authority banned Muslim girls from wearing the hijab at the municipal public primary schools. ${ }^{220}$ More recently the Dutch have focused on the veil again, this time it is the niqab and burka in the spotlight.

In 2003 the Commission for Equal Treatment sanctioned a ban on the niqab, citing similar reasons put forward by the school in West Yorkshire; the niqab restricts communication between teachers and their pupils. ${ }^{221}$ Also in 2003 the niqab came to the attention of the Municipality of Eindhoven which

\footnotetext{
${ }^{215}$ Bahriye Ucok MP Social Democratic Populist Party.

${ }^{216}$ Smith H, 'Judge Shot Dead in Turkish Court over Ban on Headscarves' The Guardian 18 May 2006.

${ }^{217}$ Ugur Mumcu Cumhuriyet columnist.

${ }^{218}$ Leyla Sahin v Turkey (Application no. 44774/98) 29 June 2004.
}

${ }^{219}$ Memorandum to the Turkish Government on Human Rights Watches Concerns with Regard to Academic Freedom in Higher Education, and Access to Higher Education for Women who Wear the Headscarf. Human Rights Watch Briefing Paper 29 June 2004, available at www.hrw.org.

${ }^{220}$ Alphen aan de Rijn, see; Shadid W and Van Koningsveld, Muslim Dress in Europe: Debates on the Headscarf, Journal of Islamic Studies, 2005 16:1 pp 35-61.

${ }^{221}$ Shadid W and Van Koningsveld, Muslim Dress in Europe: Debates on the Headscarf, Journal of Islamic Studies, 2005 16:1 pp 35-61. 
decided, although no female official intended to wear it, a prohibition of the niqab was considered necessary. ${ }^{222}$

The most recent veil issue in Holland regards the burka. Rita Verdonk, Minister of Immigration and Integration leader of the Christian Democrat Appeal Party has stated that on forming a government, her party would ban the burka in all public places, including in the street. Criticised as a political stunt, the move is said to be aimed at public security. The ban will apply also to ski masks and helmets, which presumably must be the cause of many problems in Holland.

Public security has been an increasingly cited reason for banning the veil in recent times. For example Italy has invoked old laws preventing the covering of ones face in public, ${ }^{223}$ which is now being applied to the veil. ${ }^{224}$ Italy is also considering making news laws banning the veil. ${ }^{225}$ The Italian Prime Minister ${ }^{226}$, in setting out why these laws are necessary makes a rather unconvincing argument, though perhaps an honest one, where he said this: "You can't cover your face, you must be seen."227 Presumably this applies to Muslims and Catholic Nuns alike. Reports of terrorists freely roaming Iraq dressed in the burka, ${ }^{228}$ as well as the recent case of a terrorist suspect escaping the British police by dressing in a niqab, ${ }^{229}$ only go to add legitimacy to a ban made on the public security basis. However such instances are rare and, as John Simpson has found, it can be rather difficult for a man to hide his large feet. ${ }^{230}$

In Belgium women were asked to remove their headscarves for photographs for identification purposes. In 1998 there were seventy six cases going through he courts on the issue. ${ }^{231}$ The UK has recently addressed this point and the Driving Standards Agency has ordered that headscarves must be removed prior to taking a driving test. ${ }^{232}$ The Belgium's took the view that

\section{${ }^{222}$ Ibid.}

${ }^{223}$ Intended to foil terrorism - against wearing masks in public.

${ }^{224}$ Fraser C 'Italy government seeks veil ban' 7 November 2006 BBC, available at; http://news.bbc.co.uk/go/pr/fr/-/1/hi/world/europe/6125302.stm.

\section{${ }^{225}$ Ibid.}

${ }^{226}$ Romano Prodi.

${ }^{227}$ Fraser C 'Italy government seeks veil ban' 7 November 2006 BBC, available at; http://news.bbc.co.uk/go/pr/fr///1/hi/world/europe/6125302.stm.

${ }^{228}$ Browne A and O'Neill S 'Suspect in Terror hunt used veil to evade arrest' The Times.

${ }^{229}$ Ibid.

${ }^{230}$ Simpson J 'News from No Man's Land' Macmillan 2002.

${ }^{231}$ Shadid W and Van Koningsveld, Muslim Dress in Europe: Debates on the Headscarf, Journal of Islamic Studies, 2005 16:1 pp35-61.

232 'New Driving Test Rule Forces Muslim Women to Remove their Veils' 16 September 2006 www.thisisLondon.co.uk. 
women who wear the headscarf ought to be photographed with it on, as this is their public identity. ${ }^{233}$

\section{IS A BAN COMPATIBLE WITH THE ECHR?}

For a ban on religious insignia in schools to be compatible with the $\mathrm{ECHR}^{234}$ it must satisfy the requirements of Article 9: ${ }^{235}$

1) Everyone has the right to freedom of thought, conscience and religion; this right includes freedom to change his religion or belief, and freedom, either alone or in community with others and in public or private, to manifest his religion or belief, in worship, teaching, practice and observance.

2) Freedom to manifest one's religion or beliefs shall be subject only to such limitations as are prescribed by law and are necessary in a democratic society in the interests of public safety, for the protection of public order, health or morals, or the protection of the rights and freedoms of others.

In order to make an assessment one must ask this; is preventing school children from wearing religious insignia an interference with Article 9? If it is, is the prohibiting provision prescribed by law; pursuant with a legitimate aim and; necessary in a democratic society?

\section{Interference}

Not every act motivated or inspired by a religion or belief is protected. ${ }^{236}$ In order to be protected, the applicant must show that wearing the religious insignia in question, is actually manifesting a religious belief, rather than being motivated by one. ${ }^{237}$ However, the wearing of insignia has been held to be a manifestation of belief for the purposes of Article 9 (1). ${ }^{238}$

233 Shadid W and Van Koningsveld, Muslim Dress in Europe: Debates on the Headscarf, Journal of Islamic Studies, 2005 16:1 pp35-61.

${ }^{234}$ European Convention on Human Rights 1950.

${ }^{235}$ For example Articles 8, 10, 14, 2 and Protocol No 1, See Leyla Sahin v Turkey (Application no. 44774/98) 29 June 2004.

${ }^{236}$ Arrowsmith $v$ United Kingdom No. 7050/75, Rep. 1978 \& Kalac v Turkey judgment of 1 July 1997.

${ }_{237}$ Arrowsmith v United Kingdom No. 7050/75, Rep. 1978 Para 71.

${ }^{238}$ Karaduman v Turkey no 16278/90 Commission decision of 3 May 1993 \& Leyla Sahin v Turkey (Application no 44774/98) 29 June 2004. 


\section{Prescribed by law}

Whether a ban on religious insignia is prescribed by law will depend on the particular provision, in the particular country, which provides for the ban. The court will look at the quality of the law in question, requiring that it should be accessible to the person concerned and foreseeable as to its effects. ${ }^{239}$ A published clear, written school uniform policy which is available to all who might be affected by it, has been held to meet this requirement by the Court of Appeal. ${ }^{240}$ The Strasbourg Court has held that circulars and regulatory provisions will also be sufficient. ${ }^{241}$

\section{Legitimate aim}

A number of legitimate aims are listed in Article 9 (2); "In the interests of public safety, for the protection of public order, health or morals, or the protection of the rights and freedoms of others." In Sahin v. Turkey ${ }^{242}$ the Turkish Government argued that a law prohibiting students from wearing the Islamic veil in university perused the aims of: maintaining order in universities, upholding the principle of secularism and protecting the rights and freedoms of others. As regards the "rights and freedoms of others" the Turkish Government was particularly concerned with freeing students who may be under pressure to wear the veil and upholding and promoting gender equality. ${ }^{243}$ The court held that these aims accorded with those listed in the second paragraph of Article 9. Further, the applicant conceded the importance of such aims, and accepted that they may be regarded as being compatible with Article 9 (2). ${ }^{244}$

Protecting the principles of secularism and neutrality, in relation to the prohibition of religious insignia in schools, has also been previously upheld as being legitimate aims for the purpose of Article 9 in Dahlab $v$ Switzerland. ${ }^{245}$ It is, therefore likely that where a state imposes a ban on religious insignia in schools, whilst following the above described aims, the Strasbourg Court will

${ }^{239}$ Leyla Sahin v Turkey (Application no. 44774/98) 29 June 2004 and Rotaru v Romania (28341/95) [2000] ECHR 191 (4 May 2000).

${ }^{240} R$ (on application of B) $v$ Headteacher and Governors of Denbigh High School 140, Court of Appeal (Civil Division) [2005] EWCA CIV 199, [2005] ALL ER per Lord Brooke Para 61.

${ }^{241}$ Leyla Sahin v Turkey (Application no. 44774/98) 29 June 2004.

${ }^{242}$ Leyla Sahin v Turkey (Application no. 44774/98) 29 June 2004.

${ }^{243}$ Ibid para 82.

${ }^{244}$ Ibid para 85.

${ }^{245}$ Dahlab v Switzerland no 42393/98 ECHR 2001. 
find that the aims are legitimate for the purpose of Article 9 (2). Nevertheless, a ban on religious insignia must be deemed necessary in a democratic society.

\section{Necessary in a democratic society}

In determining the issue of necessity, the Strasbourg Court will look to make a careful balance between the rights at stake, on the one hand, and the effects of the ban on the other. The Court explained its role in Dahlab, where it said "The Court's task is to determine whether the measures taken at national level were justified in principle - that is, whether the reasons adduced to justify them appear "relevant and sufficient" and are proportionate to the legitimate aim pursued... In order to rule on this latter point, the Court must weigh the requirements of the protection of the rights and liberties of others against the conduct of which the applicant stood accused. In exercising the supervisory jurisdiction, the court must look at the impugned judicial decisions against the background of the case as a whole..." ${ }^{246}$

In Dahlab, where a teacher brought an action against a school which had prohibited her from wearing the Islamic veil whilst at work, the Swiss Government argued that the veil was incompatible with the aims perused; it constitutes a "powerful external symbol" which might have some kind of "proselytising effect, seeing that it appeared to be imposed on women by a precept laid down in the Koran".(no citation or ibid?) This, it was argued, was "hard to reconcile with the principle of gender equality". The court upheld these arguments as being necessary to protect secularism and school neutrality.

In Sahin, the most recent Strasbourg authority on religious insignia in schools, the Turkish Governments arguments were based on similar grounds; the protection of secularism and gender equality. In following Dahlab, the court gave consideration to the "impugned judicial decisions against the background of the case as a whole". Here Turkish history was relevant. Turkey is a country with a history of religiously motivated political movements aimed at destabilising its democracy. ${ }^{247}$ The Islamic veil, in the Turkish context, is a symbol which attaches fundamentalist political significance. In this regard the veil exerts a form of pressure on university students and adversely affects the principle of gender equality. Secularism, Turkey submitted, is, inter alia, the guarantor of democratic values, upon which the Turkish constitution is based. Further, the notions of secularism and

${ }^{246}$ Dahlab v Switzerland no. 42393/98 ECHR 2001, P11.

247 Refah Partisi \& Others $v$ Turkey, nos 41340/98, 41342/98, 41343/98 and 41344/98, ECHR 2003. 
gender equality are consistent with the values underpinning the Convention. $^{248}$

Turkey also argued that in addition to being necessary for the above described reasons, the prohibiting law was proportionate. The Government did not seek to limit the freedom to wear religious insignia outside of university. Further, Muslim students are free to "perform the religious duties that are part of Muslim observance." ${ }^{249}$ (This seems strange given that the limitations are placed exactly in that regard). In addition, universities treated all forms of dress symbolising or manifesting a religion or faith on an equal footing. In accepting the submissions made by Turkey, the court said this; "In a country like Turkey, where the great majority of the population belong to a particular religion, measures taken in universities to prevent certain fundamentalist religious movements from exerting pressure on students who do not practise that religion or on those who belong to another religion may be justified under Article 9(2) of the Convention.". ${ }^{250}$ Such a law banning insignia in schools is therefore "proportionate to the aims perused....and...necessary in a democratic society", ${ }^{251}$ at least in Convention terms.

The Strasbourg court will allow a member state a margin of appreciation. "A margin of appreciation is particularly appropriate when it comes to the regulation by the Contracting States of the wearing of religious symbols in teaching institutions, since rules on the subject vary from one country to another depending on national traditions." ${ }^{252}$ Whilst this notion allows states considerable room for manoeuvre ${ }^{253}$, it does not exclude European supervision $^{254}$ and in light of Sahin, the context would appear to be of great importance.

To summarise: preventing school children from wearing religious insignia in schools interferes with their rights provided by Article 9 (1). However, doing so may be consistent with the ECHR if the ban is firstly a law or regulation which is clear, precise and accessible. Secondly a legitimate aim must have been pursued and this has been held to include defending the principles of secularity, gender equality and the rights and freedoms of other students. Lastly a ban must be considered to be necessary and this will only be the case if it strikes the correct balance between the rights and freedoms, on

\footnotetext{
${ }^{248}$ Leyla Sahin v Turkey (Application no. 44774/98) 29 June 2004 para 106.

${ }^{249}$ Ibid para 111.

${ }^{250}$ Ibid para 101.

${ }^{251}$ Ibid para 114.

252 Ibid para 102.

${ }^{253}$ Hatton and Others $v$ United Kingdom (36022/97) [2001] ECHR 561 (2 October 2001).

${ }^{254}$ Ibid para 102.
} 
the one hand, and the proportionality of the measures on the other, but to that end states are afforded a wide margin of appreciation.

\section{INTERNATIONAL LEGAL STANDARDS}

Article 18 of the Universal Declaration on Human Rights provides "Everyone has the right to freedom of thought, conscience and religion; this right includes freedom to change his religion or belief, and freedom, either alone or in community with others and in public or private, to manifest his religion or belief in teaching, practice, worship and observance." Article 2 of the International Covenant on Civil and Political Rights (ICCPR) obliges all state parties to "respect the rights set forth in these documents without distinction of any kind, such as race, colour, sex, language, religion, political or other opinion, national or social origin, property or other status."

Under Article 18 (1) ICCPR "Everyone shall have the right to freedom of thought, conscience and religion. This right shall include freedom to have or to adapt a religion or belief of his choice, and freedom individually or in community with others and in public or private, to manifest his religion or belief in worship, observance, practice and teaching." General Comment number 22 of the United Nations Human Rights Committee states that this includes the wearing of "distinctive religious clothing or head coverings." A ban on the Muslim headscarf clearly violates this provision.

Article 18 (3) ICCPR provides the rights in Article 18 (1) above may be limited where "necessary to protect public safety, order, health, or morals or the fundamental rights and freedoms of others." The Committee has stated that "restrictions may not be imposed for discriminatory purposes or applied in a discriminatory manner." 256 Many headscarf bans are verging on this, particularly as often seems to be the case, a prohibition is aimed at Islam. Article 19 ICCPR provides for freedom of expression which also protects the wearing of the headscarf.

Article 13 of the international Covenant on Economics, Social and Cultural Rights establishes the right to higher education. This "shall be accessible to all." Under Article 2 (2) religion is prohibited as a permissible ground for distinction. A ban on the headscarf in institutions of higher education will deny education to those who wear the headscarf, thus violating this right.

Under Article 10 of the Convention of all Forms of Discrimination Against Women "State parties shall take all appropriate measures to eliminate

${ }^{255}$ General Comment Number 22 of the United Nations Human Rights Committee, adopted on 20 July 1993 Doc CCPR/C/21/Rev1/Add 4.

${ }^{256}$ Ibid. 
discrimination against women in order to ensure to them equal rights with men in the field of education and in particular to ensure, on a basis of equality of men and women." A prohibition on the veil will always apply disproportionately to women, which, additionally to being discriminatory, consequently fails to provide for equality in the field of education.

The text of the international legal provisions which apply to a ban of the headscarf therefore sets out a high threshold which must be met by a state party perpetrating a prohibition. A ban must be made by the least restrictive means possible, be non-discriminatory in its nature and it must be proportionate with a legitimate aim. For many of the bans discussed above, it is doubtful whether these standards have been met.

\section{CONCLUSIONS}

The wearing of the Muslim headscarf transcends a wide range of issues producing much debate in western countries, often provoking broad based and emotional responses. This in turn leads to different consequences in both policy and law, which as with the debates themselves differs from one State to another. The issue is considered so important that in some countries only a legislative ban will suffice. In others, courts will rule against freedom of religion in upholding bans which are made with little consideration for religion and tolerance alike.

International law presents a clear defence of the right of an individual to wear insignia attesting to their religious beliefs, in all social contexts. This includes the right to wear Islamic head coverings in the public sphere. The European Convention on Human Rights affords considerable protection in respect of the same. Domestic legal provisions in many European countries, for example France, conflict with these rights. Even in countries where direct legislative bans have not been made, institutions, such as schools, continue to deny religious freedom to those who wish to wear Islamic head coverings. Courts have primarily upheld bans on the headscarf, interpreting the law restrictively. ${ }^{257}$ However, with so many prohibitions on the wearing of the headscarf in Europe, a trend which looks set to continue, the limits of Article 9 ECHR are likely to be tested further.

The position taken by the United States has differed considerably with that taken in Europe and of all the countries examined in this article the US has been the least compromising in its defence of the rights of its children to wear religious dress in school. In the words of Mr Justice Fortus: "It can

${ }^{257}$ Leyla Sahin v Turkey Application 44774/98 ECHR;

${ }^{258} R$ (On the Application of Begum) v Headteacher and Governors of Denbigh High School HL [2006] UKHL 15, [2006] ALL ER (D) 320 (MAR) (Approved Judgement). 
hardly be argued that either students or teachers shed their constitutional rights to freedom of expression at the school gates." ${ }^{258}$ The domestic courts in Europe, additionally the Strasbourg Court in particular, may wish to take note of this and have it in mind when, as seems inevitable, the next headscarf case arrives at a court door.

The issue of proportionality has and will continue to be central to debates and court cases involving the prohibition of the headscarf. Any ban will be considered not only in light of the right to religious expression in dress, but also the rights and freedoms of others. ${ }^{259}$ This is not a straight forward or easy issue to decide. It was argued in Canada that consideration of religious rights must be counter-balanced by considerations of "undue hardship" with regard to the accommodating party. ${ }^{260}$ Canada often appears to draw the line at Health \& Safety hazards. ${ }^{261}$ In Europe it has been considered that an individual's face must be fully visible for the purposes of official photographs. ${ }^{262}$ However all too often the arguments advanced in favour of restricting the wearing of the headscarf are weak and at times seem prejudicial.

The most specific issue which the courts will likely be asked to decide is whether a ban on a wearing the full faced veil such as the niqab in schools or courts can be justified. It would seem that a careful approach must be taken. It is of course quite proper that the rights and freedoms of others are important and due weight must be given to that end. In a multicultural society limitations will have to be made. If a teacher cannot be understood by her pupils then they cannot learn. If a lawyer is unable to communicate a client's case to the court then justice cannot prevail.

But it is how and to what extent restrictions are made which seems to be where many European countries get it wrong. Human Rights provisions exist for a purpose. It is simply not right that a state can prohibit religious freedom and manifestation of religious belief on the most flimsy of reasons. It is not right to deny school children their legal rights because others feel they do not "fit in". It will not do to make bans because some in society merely do not like the headscarf. Those who feel women are oppressed by the headscarf may wish to argue that in open debate, but to make legislative bans for such

\footnotetext{
${ }^{259}$ Tinker v Des Moines School District, 393 US 503 (1969).

${ }^{260}$ Article 9 (2) ECHR; Article 18 (3) ICCPR.

${ }^{261}$ Ontario Human Rights Commission and O'Malley v Simpsons-Sears (1985) 2 SCR 536551 .
}

${ }^{262}$ Shariff S, Balancing Competing Rights: A Stakeholder Model for Democratic Schools, Canadian Journal of Education 29, 2 (2006) 476-496.

${ }^{263}$ For example in the UK see: New Driving Test Rule Forces Muslim Women to Remove their Veils' 16 September 2006 www.thisisLondon.co.uk. 
reasons is oppressive in itself and moreover can hardly be said to satisfy the requirements set out in Article 9 (2).

The law therefore requires high standards of necessity so that a ban is strictly required for compelling reasons, ${ }^{263}$ but many European countries appear to form policy enacting bans on the headscarf for reasons which merely reflect the political concerns of their people. Such concerns often do not amount to reasons sufficiently compelling to justify prohibition as required by the standards of limitation provisions, such as Article 9 (2) of the ECHR.

States of course know this, and know that if a ban is to be lawful, limitation provisions must be met. Inevitably they will attempt to reach them to legally justify a ban. This transpires where arguments for the prohibition of the headscarf are made on grounds such as public security or the defence of secularism, but the headscarf is then attacked on other fronts not stated as the bans primary aim. For example, why if France was merely concerned with maintaining religious neutrality in state schools, did so much of the focus concentrate on the concern or the perception that the headscarf was oppressive to women? A noble cause the eradication of the oppression of women undoubtedly is, but to presume that the headscarf is inexorably an indicator of oppression is overly presumptive and further it is not the same argument as religious neutrality.

Though the position relating to bans on the headscarf in most of the countries discussed remains in a developing state and often lacks clarity, it is clear that international law requires that high standards must be met. Presently the words found in the text of so many limitation provisions in human rights treaties such as "necessary" and "proportionate" do not seem to be understood.

${ }^{264}$ ECHR Article 9 (2); ICCPR Article 18 (3). 